\title{
Primary Neoplasm
}

National Cancer Institute

\section{Source}

National Cancer Institute. Primary Neoplasm. NCI Thesaurus. Code C8509.

A tumor at the original site of origin. 